\title{
Strategic Academia - Industry Partnerships, Incubations and their Outcomes: A Holistic View
}

\author{
Joghee Shanmugan $^{1 *}$, Sajal Kabiraj ${ }^{2}$
}

\begin{abstract}
${ }^{1}$ Assistant Professor in Business Management, Skyline University College, University City of Sharjah, UAE ${ }^{2}$ Professor in Business Management, Dongbei University of Finance and Economics, Dalian, CHINA

*Corresponding Author: jshanmugan@skylineuniversity.ac.ae
\end{abstract}

Citation: Shanmugan, J., \& Kabiraj, S. (2018). Strategic Academia - Industry Partnerships, Incubations and their Outcomes: A Holistic View. Mediterranean Journal of Social \& Behavioral Research, 2(1), 9-17. https://doi.org/10.30935/mjosbr/8382

\begin{abstract}
Academia-industry partnerships have been discussed before by many researchers and during the last two decades and academic spin-offs have received increasing attention from both researchers and practitioners, mainly due to their ability to advance industrial application of scientific knowledge. (Barbara et al, 2013). The outcomes of these spin-offs have not generated much enthusiasm amongst the industry due to consistent failures. This fact can be attributed to the fact that there are concerns which needs to be addressed like clear guidelines on joint ownerships, IP ownership patterns, patents, profit sharing and technology transfer norms amongst others. The idea that universities should go beyond education and research and undertake a third mission of direct interaction and contribution to the industry has found increased attention in past decade. This direct interaction and contribution in the form of university incubations and spinoffs provides a win-win situation for both universities as well as the industry. However, it is not easy to manage these university start-ups. This paper makes an attempt to explore the challenges faced by university spinoffs and present incubators as a potential enabler to overcome such challenges. The study identifies some of the important challenges that university spinoffs face such as product development, technology push problem, finances, market uncertainty, human capital and business strategy. The research tries to facilitate the establishment of clear guidelines for collaborative win-win partnership amongst academia and industry.
\end{abstract}

Keywords: university industry linkages, spin-offs, product development, technology, human capital

Received: 15 Dec. 2017 Accepted: 8 Feb. 2018

\section{INTRODUCTION}

There is little doubt that universities play an important role in regional and nation's economic development through education and research. In fact scholars have also promoted the idea that universities should go beyond education and research and undertake the third mission of direct interaction and contribution to the industry (Etzkowitz \& Leydesdorff, 2000; Slaughter \& Leslie, 1997). Jaffe (1989) assert that the relationship of research conducted by either university or the industry and innovation has been a matter of extensive research. There are many ways by which industry - university linkages are formed. These linkages include the employment of university graduates in the industry, formal and informal interactions, consultancy work, joint research programs, licensing university patents, and purchase of prototypes by the industry, etc. (D'Este \& Patel, 2007).

It has been recently realized that universities and research centres can play a strategic role in creating and fostering innovation and thereby making direct contribution towards the regional development. It has also been reported that universities are aware of the fact that they can make use of their own research results by promoting and sustaining the creation of new ventures. This kind of mediation through which new ventures are created is known as spin offs. University spinoffs are confronted with several challenges before they become viable and achieve a level of self-sustenance. This paper makes an attempt to explore the kind of challenges faced by university spin-offs. Paper also discusses the role of university business incubators as enablers for successful university spinoffs.

In section 2, paper commences by introducing the role of universities in traditional as well as contemporary times. This is followed by the discussion on university industry linkages in section 3 . Definition of university spinoffs is explored in section 4 and Challenges in the management of university spinoffs are discussed in the section 5 . Role of incubators in facilitating spinoffs is presented in section 5. Paper closes with discussion and conclusion in section 6 .

\section{CHANGING ROLE OF UNIVERSITIES}

University's role in the overall socio-economic environment of any country has been extensive and undeniable. The roles can be broadly classified as generative and developmental. Generative role can also be 
Table 1. Changes in the University System from the Traditional to Contemporary Roles

\begin{tabular}{|c|c|c|}
\hline & Traditional Role & Contemporary Role \\
\hline Fundamental Role & Conducting basic research and training human resources & Direct contribution to socio-economic development \\
\hline $\begin{array}{l}\text { Type of and Reason } \\
\text { for Research }\end{array}$ & Basic, driven by the spirit of inquiry and usually non specific & Applied, driven by the need to commercialize it to the industry \\
\hline Pros & $\begin{array}{l}\text { Advancement of knowledge. } \\
\text { Functions as an autonomous or a stand -alone body. } \\
\text { Creates new knowledge and expands existing knowledge }\end{array}$ & $\begin{array}{l}\text { Facilitates the translation of knowledge into end use. Contributes to } \\
\text { the overall socio - economic development of the society directly } \\
\text { though creation of employment and business opportunities. }\end{array}$ \\
\hline Cons & $\begin{array}{l}\text { Created knowledge might be irrelevant to the industry resulting in } \\
\text { usage of resources, physical as well as mental, without any tangible } \\
\text { benefits to the society. }\end{array}$ & $\begin{array}{l}\text { Identity crisis of the universities as they may move away from doing } \\
\text { what they do best. } \\
\text { Might impact the speed of expansion of knowledge which was } \\
\text { possible through the conduct of basic research. } \\
\text { Creation of a profit motive for research rather than a pure inquiry } \\
\text { based motive for the same. }\end{array}$ \\
\hline Emphasis & $\begin{array}{l}\text { Heavy emphasis on creation and expansion of knowledge through } \\
\text { research and dissemination of the same through training. For } \\
\text { example: University policies on intellectual property. }\end{array}$ & $\begin{array}{l}\text { Shifted emphasis on more application type research which can be } \\
\text { adopted by the industry to create solutions for end use. For example: } \\
\text { Legislative action through laws. }\end{array}$ \\
\hline
\end{tabular}

seen as traditional role which universities have been following since their inception and developmental role can be seen as the contemporary which is more advanced to engage universities with the industry.

\section{Traditional Role of the University}

Traditionally universities have been only concerned with the conduct of research and training. They contribute to the overall growth by creating the much needed human resource through training, enriching skills and conducting advanced research in terms of scientific and technological enhancements (Mowery \& Sampat, 2005).The impact of universities, traditionally, has been indirect.

This has been termed as the generative role of the universities and was limited to the production of science for the society and did not include the production of industry acceptable solutions by way of applied science. Many authors have accepted universities in the generative role. In their research, authors like Cohen and Nelson found out that the basic research conducted by universities hardly plays any role in the industrial development of nations (Cohen et al., 2002). Others like Lundvall and Johnson (1994) suggest that the most important contribution of universities to the society still remain to be train human resources and impart skills.

\section{Contemporary Role of the University}

Lately, both the society and the industry has entrusted universities with an additional responsibility of creation of applied knowledge that can be captured by the industry directly in order to achieve economic growth and development. Lundvall and Johnson (1994) argues that direct contact with the industry might limit the scope of research and development activities of the universities that might result in negative impacts in the future by restricting creativity of researchers to create science rather than just solutions for the industry. In terms of research and development, on one hand such activities in the industry are application based or incremental, universities aim to explore the present scientific knowledge so that they can stretch it to include new knowledge. This is so because the industry has limitations of time and funds and most importantly need to guard themselves against competition. This creates the need for strong protection of the created knowledge as well as its management in order to be able to commercialize that knowledge for use downstream. University on the other hand, is led by the spirit of inquiry which more often than not is funded by either the industry or the state. Authors like Leydesdorff and
Etzkowitz (1998) have argued that universities have now begun behaving like entrepreneurs who identify a need and then create and provide solutions and thus have now become more like the industry. Table 1 presents the role of universities in the traditional and contemporary set up.

\section{UNIVERSITY INDUSTRY LINKAGES}

There is little doubt that the linkage between universities and industry is probably as old as the university system itself. As also evident from the table above, universities have made a shift from generative to developmental activities. University industry linkages are important to industry as well as the university and both draw advantages from each other. Peters and Fusfeld (1982) pointed some of the reasons why university needs the support of the industry. The most important being access to funds for research and scientific endeavors of the university with lesser bureaucracy involved. Industry also helps the scholars and scientists to understand the pulse of market and also it helps in developing a fascination for science in practice. Universities also license outs the IP to the industry which helps in the generation of cash for future research activities and gives financial freedom to the university.

Similarly, the reasons for the industry's interest in the university according to Atlan (1987) are unlimited access to skilled human resources; availability of both fundamental as well as application based research results that can be translated into products and services for end use; skills and infrastructure available only in the universities; creating goodwill in the society because of links with universities and getting faculty as consultants. Figure 1 pictorially represents the university industry linkage.

\section{WHAT ARE UNIVERSITY SPIN-OFFS?}

Literature is replete with the definitions of university spinoffs wherein authors have proposed their understanding in different manners. Shane (2004) defines university spinoff as a new company founded to exploit a piece of intellectual property created in an academic institution. Spinoff, also known as 'start ups' and 'spinout' also means leaving "the parent organization, taking along a technology that serves as the entry ticket for the new company in a high-technology 


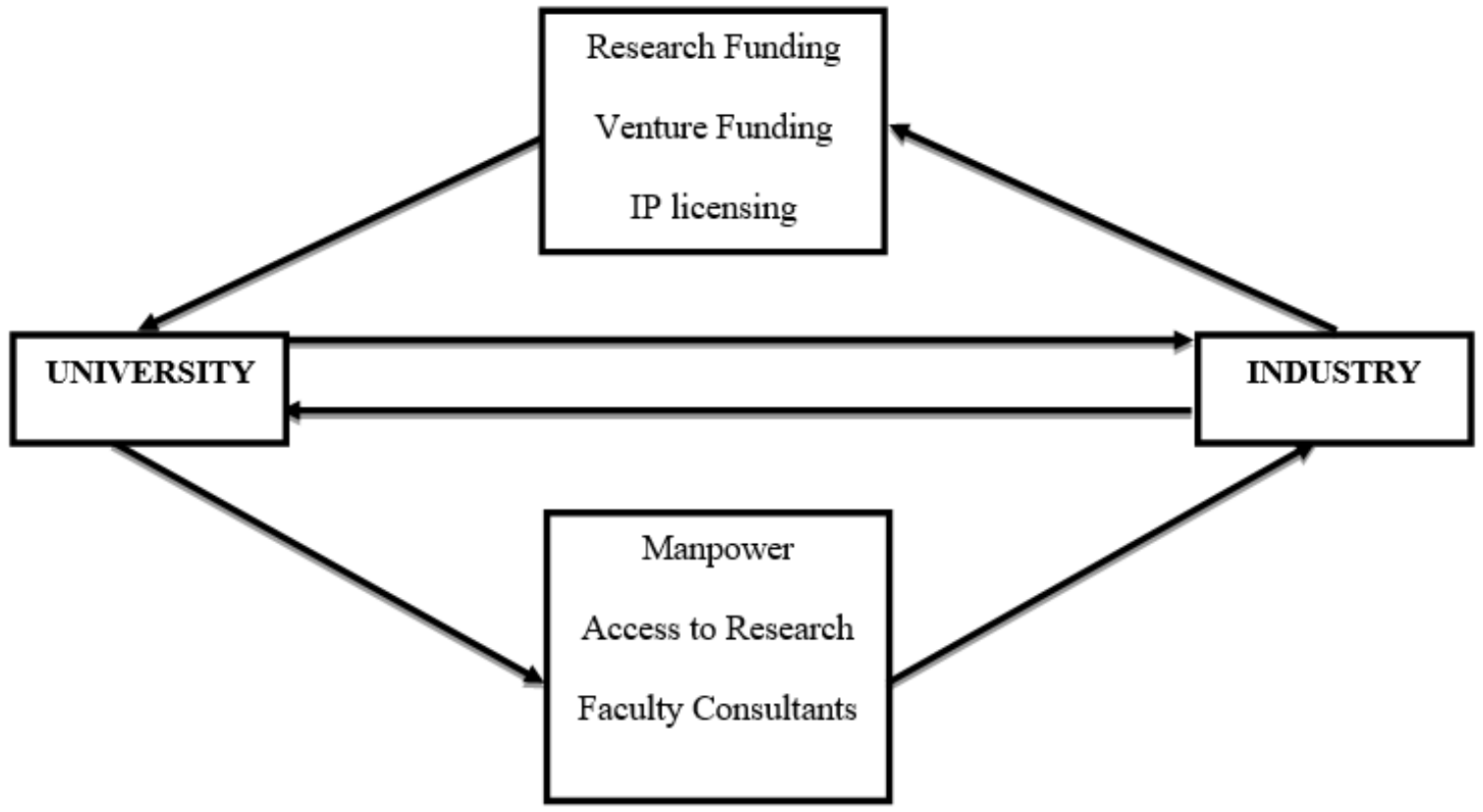

Figure 1. University - Industry Linkages

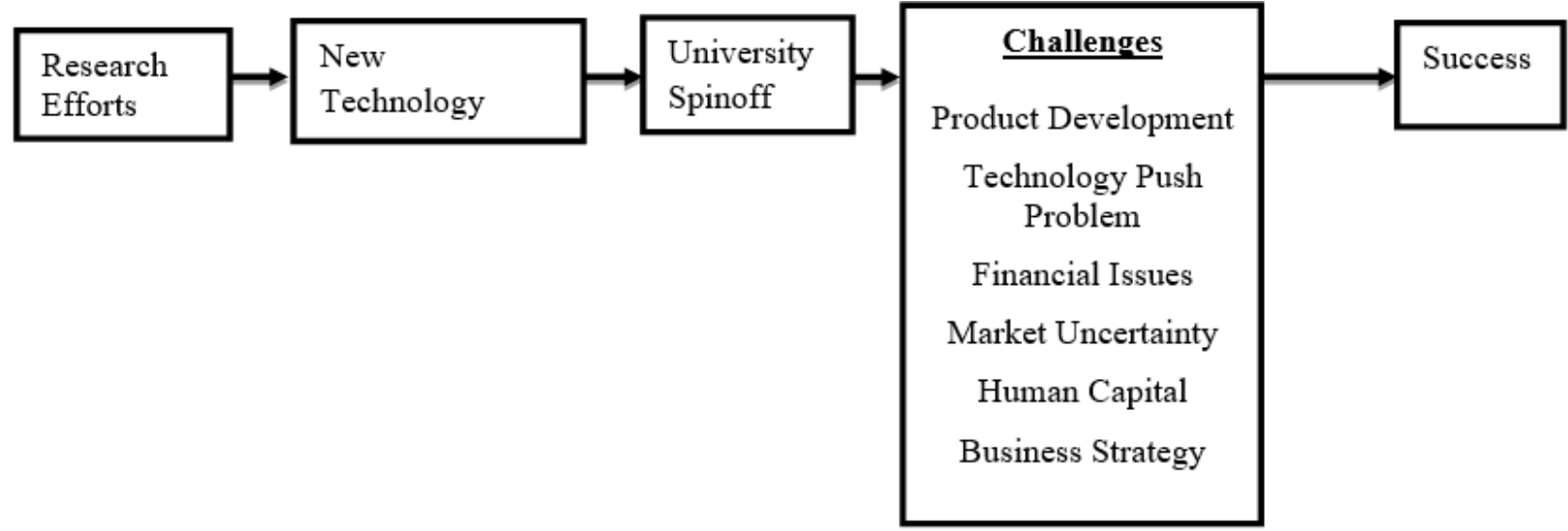

Figure 2. Translation of Research Efforts to Success in University Spinoffs

industry" (Carayannis et al., 1998). Locket and Wright (2005) defined university spin-outs as "new ventures that are dependent upon licensing or assignment of the institution's intellectual property for initiation." The above definition does not include the companies which are not based on technology assigned/ licensed from the universities i.e. the companies which are not directly associated to intellectual assets created from research and funded by the government or the industry. In order to commercialize, technology is moved to a separate, new venture and this development is known as spinning off (Gorling, 2006). "An entrepreneurial spin-off arises when an entrepreneur leaves an organization to start a firm of his/her own. Hence, university spin-out is a separate venture and involves a specially formed team of people" (van Gorp \& Jagersma, 2004) i.e. a faculty member, staff member or a student (Smilor et al., 1990).

One of the widely accepted definitions of spinoff given by Nicolaou and Birley (2003) suggest that "Spinouts involves transfer of a core technology from an academic institution into a new company and the founding member(s) may include the inventor academic(s) who may or may not be currently affiliated with the academic institution".

\section{CHALLENGES IN MANAGEMENT OF UNIVERSITY SPIN-OFFS}

Spin-offs face several challenges in all the phases right from the establishment, to productization and getting finance. Drawing from the available literature this section discusses some of the most important challenges in the management of university spinoffs (see Figure 2).

\section{Product Development}

Since the research results are often at a basic stage, spinoffs have to conduct more research to make it appropriate for the commercial usage. This product development process involves two activities. First, turning the university invention into a product or service. Second, making sure that those products or services meet the standards of the commercial environment.

Productizing the Invention: To have a commercial product or service, the founders of a university spinoff must transform the technology into something that solves a customer need or problem (Zahra, 1996). The ability of a firm to develop, improve and generate new products/services faster than anybody else can be more effective, 
generating higher barriers to competitors (Stalk \& Hout, 1990). Keeping this in mind, the founders of university spinoffs must transform their university technologies into products or services for several reasons. First, most customers generally do not buy the technology, but, instead, buy products or services. Therefore, the spinoffs need to create something that customers will buy. Second, many customers of new technology products and services do not purchase the technology alone, but instead purchase solutions to their problems. As a result, they are interested in products and services that combine the new technology with standard features that competitor products and services have, such as appropriate documentation, packaging, support services, and so on. To attract customers, the spinoff needs to minimize any differences between its products and services on standard dimensions that all products and services have, and provide features that are not possible in competitor products or services. Therefore, the founders of spinoffs often need to create the standard attributes of products and services before their technologies can be considered products or services. Third, the university technology must be changed into a form that meets actual customer needs. Because university technology is often created without the goal of satisfying customer needs, potential customers often do not find that university technology in raw form satisfies their needs or solves their problems. Fourth, the creation of a product or service allows the spinoff to obtain additional intellectual property protection on its technology. While university spinoffs often begin with licenses to patented inventions, they can acquire additional protection on their technologies by obtaining patents on the designs of their products or on special features of products or services that they develop. These additional patents provide added intellectual property protection for the spinoff (Applegate \& Gogan, 1995)

This is one of the major challenges faced by these university spinoffs. Due to the lack of an industrial culture, they, at times under value the significance of product development and at some other times they proper product development does not happen at these enterprises because they just lack the knowledge of the process of developing a product. As discussed earlier in the chapter, this goes back to the traditional role of the universities in conducting fundamental research and training human resources rather than spending sufficient time in mastering the techniques of product development or in other ancillary management functions (Merton, 1973).

The founders of university spinoffs often find the product development process quite challenging because it is not always a direct extension of the research that led to the invention on which the spinoff is founded. In many cases, the technology itself does not indicate what type of product should be created, and the founders of the spinoff have to figure out what product or service to make from the invention. Therefore, the amount of activity that needs to be undertaken by the spinoff in product development is often quite large. In general, to develop a commercial product for a university technology takes an average of four years and $\$ 4$ million after the spinoff is founded, with revenues from the successful commercialization effort not coming until the eighth or ninth year after licensing (Bee, 2004).

The main reason why product development times for university spinoffs are so long is that university technologies are at such an early stage at the time that the spinoffs are founded. As a result, the founders need to undertake steps - proving the principle, developing a prototype and then conducting product development - to transform their technology into products and services.

The long product development times for university spinoffs create several difficulties for the management of the process. The first problem is that markets do not stand still while product development is being undertaken. Customer needs shift and competitors launch products, changing the necessary features and characteristics of the spinoff's product or service. As a result, many university spinoffs miss their market opportunities. A second problem that long product development times create is that they lead founders of university spinoffs to underestimate the time and money that it will take to develop a successful spinoff. This underestimation of the time and effort that it takes to create products and services from university technology means that the efforts of many university spinoffs are unsuccessful because the founders do not obtain sufficient human or financial resources to complete the process.

Developing a product or service from a university invention is also highly uncertain. Because the founders of spinoffs must often change university technologies to create products or services, many university spinoffs face considerable technical uncertainty even after they have developed prototypes. Among the aspects of technical uncertainty that founders face are whether the technology will adapt to the commercial environment, whether the founders have the competence to turn a university invention into a product and whether complementary technologies necessary to support a product or service will be developed in time. This uncertainty involves both questions about technical possibilities and questions about founder competence. First, there is uncertainty because no one knows if the changes that would be required to make something commercially viable are physically possible. Second, there is uncertainty because no one knows if the founders of the spinoffs are capable of making these changes even if they are physically possible (Vohora et al., 2004).

\section{Technology Push Problem}

University Spinoffs often originate because of the efforts of either the university or the inventor who have access to viable research results or technologies. Since the origin is attached to a research result that has patent protection, it is novel and non - obvious in addition to being useful. Owing to its novelty, the same technology would not be in use anywhere in the market prior to it being adopted by a spinoff and thus is pushed from the university to the market via the spinoff. However, as has been explained earlier, academics create new technologies as a by-product of their research activities, and not because they are asked to come up with technical solutions to specific customer problems. This, though, does not impede the growth potential of a spinoff once it adopts a new technology. In the modern world with tough competition and fast changing customer tastes and preferences, it is new technology that might as well provide competitive advantage and therefore break the superior power enjoyed by the established companies. It might in fact guarantee success in the longer run for the spinoff (Tushman \& Anderson, 1986). By having new technology spinoffs might find a niche to operate in the market satisfying demands that were earlier either not identified or were unsatisfied. It might even create a market leadership position for the spinoff with the first movers' advantage of adopting a new technology and adapting it to satisfy market demands (Kerin et al., 1992). However, developing radical technologies may be risky because it demands extensive investments in $\mathrm{R} \& \mathrm{D}$, market development and customer education (Ali, 1994). Consequently, after establishing their 
companies, the founders of university spinoffs need to identify specific customer problems that their new technologies can be used to solve and need to turn their technologies into products and services that solve those problems.

In a sense, technology push refers to a technological solution in search of a problem. A technology "push," is also known as top down transfer where a new invention is pushed through $R \& D$, production and sales functions onto the market without proper consideration of whether or not it satisfies a user need (Martin, 1994).

With all the potential benefits of adopting new technologies, research has found out that usually spinoffs opt for general-purpose technologies which have varies usage rather than radical technologies to translate them to end products and services (Nelson, 1991). These technologies offer multiple market applications to exploit, allowing entrepreneurs to change direction if one application fails to perform or cannot generate a large enough market to support the new firm. As a result, established companies tend to cede general-purpose technologies to new firms, allowing spinoffs to enter markets without facing immediate competition. Some observers also explain that generalpurpose technologies enhance the performance of university spinoffs for cash flow reasons. Because a general purpose technology has multiple uses, the founder of a spinoff can exploit one application for early cash flow and then another target application in a larger market once that first application has been exploited successfully (Tornatzky, 1995).

\section{Financial Issues}

University spinoffs require significant amounts of capital. The need for spinoffs to conduct significant technical and market development after founding makes them capital-intensive start-ups. Obtaining adequate capital facilitates the development of university spinoffs for several reasons (Aldrich, 1999). First, capital provides time that allows new companies to adapt to adverse environmental conditions, thereby allowing entrepreneurs to consider a wider range of potential alternatives and enhancing external perceptions of the stability, acceptability and dependability of new ventures (Shane, 2003). Second, obtaining adequate amounts of capital enhances the performance of university spinoffs. Because of the importance to university spinoffs of raising external capital, the entrepreneur typically seeks funding from investors after founding a spinoff. The process of obtaining capital from private sources usually requires issuing equity to investors and going through several investment rounds (Roberts \& Malonet, 1996).

The initial capital obtained by university spinoffs in areas other than biotechnology generally does not come from private investors, creating a funding gap in the development of university spinoffs. Such investors generally do not invest in university spinoffs when they are first founded. The bias of private investors in university spinoffs toward later stage investing means that the founders of university spinoffs often have trouble raising seed stage capital from private sector sources.

University makes financing spinoff companies difficult in three ways. First, it makes the evaluation of opportunities by investors difficult (Shane \& Stuart, 2002). Second, it creates bargaining problems between entrepreneurs and investors by leading the entrepreneurs and investors to disagree about the profitability of the opportunity $(\mathrm{Wu}$, 1989). Third, it leads investors to seek collateral to minimize the magnitude of investors' loss in the event of failure (Casson, 1982). In particular, government grants and contracts are often the major source of revenue for university spinoffs during the initial period of technology development and allow those companies to develop their technology to the point where the spinoffs can achieve private sector financing.

\section{Market Uncertainty}

When university spinoffs are established, they often face significant market uncertainty because no one knows whether the spinoff can provide a product or service that customers want or need, or that is better than the alternatives offered by competitors. Some of the reasons for this are as follows:

First, several spinoffs face the uncertainty of whether or not there is customer demand for the product or service provided by the spinoff. In addition to determining whether there is demand at all, the founders of university spinoffs need to determine the volume of that demand. Secondly, for the spinoff to be successful, the volume of demand has to be large enough to support the development of a new company. Thirdly, overcoming market uncertainty also means coming up with a product or service that customers are willing to pay for, rather than viewing it as something that they should receive for nothing. Even if the spinoff creates a product or service that customers want and will pay for, the founders face the uncertainty of whether or not the spinoff can produce the product or service economically. Producing a product or service economically means that it can be created at a cost less than the price that customers are willing to pay. Fourth dimension of market uncertainty is whether the spinoff's product or service provides a better solution to customer needs than the alternative provided by competitors. While a spinoff's product or service may meet a customer need in a cost-effective manner, it will not generate significant sales if its competitors satisfy customer needs more effectively than it does.

Moreover, selling the products and services developed by a university spinoff is particularly difficult, for several reasons. First, in most cases, customers of new technology products and services have problems or issues that require the development of a unique approach to selling to them. Therefore, convincing customers of the value of a technology often requires different activities for each segment of the market. Second, the founders of the university spinoffs need to persuade customers to purchase enough units of the new product or service for the company to generate enough revenues to survive.

\section{Human Capital}

University spinoffs are founded with little more than the technology that the new company will exploit and the attributes of the founders who create the companies. Motivation and commitment of the founder are central to the success of the university spinoff. It is also necessary that they have a grasp of the market as well as operations to be able to pass the turbulent initial states of the company. In the particular context of university spinoffs, researchers have shown that the performance implications of Complementary teams, Business knowledge of the founder/s, Inventor Involvement and the commitment of the entrepreneurs are important and needs to be looked at.

Complementary Teams: Available literature shows that the chance of survival for a spinoff is comparatively higher if it has a decent team to start which is dedicated and technically sound (Feeser \& Willard, 1990; Heirman \& Clarysse, 2007). In fact some researchers have also argued that the more heterogeneous the team, higher the chances of success. Roberts (1991) found that companies with multiple founders 
tended to perform better on a variety of performance measures than companies with a single founder. He explained this result by arguing that ventures created by multiple founders are more likely than single founder ventures to have a founding team composed of people with expertise in all functional areas of the firm, and ventures with a more complementary team of founders perform better than those with a less complementary team. Other observers like Doutriaux and Barker (1995) and Chrisman et al., (1995) have built upon Roberts' (1991) argument, positing that university spinoffs founded by a team that involves both the inventor and people with significant industry experience tend to perform better than other university spinoffs. In addition, spinoffs with complementary teams that include people who come from both academia and industry perform better than other spinoffs because successful university spinoffs need people who have knowledge of the segment of industry in which the new company will operate, as well as people with knowledge of the technology who can continue to develop it.

\section{Business Strategy and Technology}

According to Mintzberg (1997), strategy is the link between the firm and its internal and external environment which consists of a flow of organizational decisions in parlance to the environment. It means strategy not only responds to external opportunities and threats but also help the firm in adapting to the fluctuations in the business environment. The fluctuations or changes that strategy aims to respond to are continuously in flux. One of the major changes in the modern world is the fast changing technology with provides opportunities and also threats externally along with internal strengths and weaknesses. Thus, strategy and technology cannot be oblivious to each other. Today it is almost impossible for firms to generate profits without using technology to control costs either by increasing efficiency or by controlling inventory costs. All these opportunities to control costs or to increase reach to the market via technology have become critical for the survival of the firm and are possible because of research and development efforts. In this regard, some researchers have argued that technology and strategy are interlinked although technology is only an element of strategic management (Rothberg, 2005).

Two important dimensions of strategy that come into play in university spinoffs are strategic focus and adaptability.

Strategic Focus: University spinoffs that adopt a focus strategy perform better than other university spinoffs, for several reasons. First, effective targeting and efficient use of resources can be achieved by a clear strategic focus. Second, it controls costs thereby reducing the need for raising expensive capital. Third, it displays confidence to funders. Finally, it ensures customer friendly business. One important limited resource that leads the founders of university spinoffs to develop a focus strategy is the human resources that are necessary to develop the new technology.

Adaptability: A second important dimension of the strategy of successful university spinoffs is adaptability. Given the Technological and market uncertainties facing university spinoffs, success over time requires the organizations to make changes to their technologies and shift market applications as outcomes are revealed. Those spinoffs whose founders adapt their strategic direction perform better than those spinoffs whose founders do not. Two types of adaptation appear to be particularly important to the development of successful spinoffs: adaptation of the technology and adaptation to market needs. Because the original technologies that university spinoffs are founded to exploit rarely work as the inventors had hoped, without substantial modification and adaptation, Stankiewicz (1994) argues that many successful university spinoffs adopt new technologies after founding.

\section{ENABLING UNIVERSITY SPIN-OFFS: UNIVERSITY BUSINESS INCUBATOR}

Spinoffs face an uphill task as they are somewhat bereft of good social ties, access to key resources and inexperience (Stinchcombe, 2000) in addition to running a high risk of closure as they might not fully understand what competition is and how it operates (Dollinger, 2003). Because of these reasons, a lot of the spinoffs cannot even survive long enough to see any signs of profits. They require hand holding in the preliminary stage in order to survive the turbulent times (Bergek \& Norrman, 2008). Business incubators assist firms in successfully navigating through the introductory stage. To be able to do that they provide firms with certain specialized services like managerial counselling, creating access to essential resources, etc. for it can result in increasing the absorptive or adaptive capacity if the spinoff. Its services also include the provision of the physical infrastructure like office space, conference rooms, etc. that are pivotal for their existence. In modern times, the emphasis of a university business incubator that specializes in harbouring spinoffs has taken shape (Rothaermel \& Thursby, 2005). Being in a university spinoff, it allows the use of university lab, library etc. The challenges of time, money and effort faced by these firms can slow the growth of the firm. Universities also have certain advantages of having spinoffs in the vicinity of the university as they can be used for training of the staff of the spinoff.

Hackett and Dilts (2004) define business incubator as a "shared office space facility that seeks to provide its' incubates with strategic, value adding intervention system of monitoring and business assistance." It is important to note that it is not only the physical infrastructure that an incubator offers but in addition to the infrastructure, it also provides the incubates with a number of managerial assistance in areas such as consultancy, industry and local liaison, legal assistance among others (Allen \& Rahman, 1985; Peters et al., 2004). Among all the services that technology incubators provides, the six most important are, physical infrastructure, managerial support, technical support, access to finance, legal services and networking.

University business incubators are specifically designed to facilitate university spinoffs and therefore in addition to the above functions, they also assist in securing finance, legal services including awareness regarding IPRs and last but not the least information regarding marketing of the end of products or services. Through these services, university business incubators keep the incidence of cost low during the initial stages of the spinoff. In his research, Mian found that business incubators and university business incubators are not that different. He concluded that university business incubators share some uniqueness. They housed university spinoff companies which were either started by faculties or graduates of the same university which is a unique thing. Private sector was involved in areas like finance and marketing alone and finally there was a strong impetus on regular performance appraisal of the spinoffs. They maintained databases and other resources on licences, technologies etc. which was of great help to spinoffs (Mian, 1994).

It is also pertinent to revisit the reason why universities should have incubation facilities where businesses can be incubated. As has been 
discussed in earlier chapter, it is clear that universities have two traditional missions of conducting research to explore and extent the boundaries of knowledge and train the human resource with such knowledge. But in recent times, a third mission of direct contribution to economic development has been bestowed on universities (Grimaldi \& Grandi, 2005). In tune with the third mission, universities have to establish links with the university in areas like collaborative research, industry funded research or even through spinoffs (Huffman \& Quigley, 2002). To be able to carry out this mission, universities have now started encouraging researchers and students to utilize the research results for direct contribution to the economy. This encouragement by the university results in university spinoffs that need some breathing space to begin with or till they learn the tricks of the industry to survive in open competition. This facility is called incubation and is provided by the university incubation centre.

These incubators are very focussed on facilitation of the transfer of knowledge created in the universities by way of technology to the industry. Another focus area is to commercialize research results either through transfer or creation of spinoff firms (Allen \& McCluskey, 1990). They are very specialized in this area and are thus very different than traditional industrial incubators. With technology, access to capital and knowledge of the process, these incubators provide spinoffs the opportunity to utilize the knowledge that they have into commercial offerings in the market. The most important contribution of such incubating facilities in universities is they are very close to the knowledge creating hub and thus are almost always first to receive information regarding any incremental technology. They help the spinoff companies to outdo the challenge of being new and small in the market. Some of their important activities are as follows:

- Nurture spinoff firms from the university itself in the initial period.

- Build infrastructure, both physical and managerial, to support spinoff firms.

- Create a network of specialized personnel in the areas of management, technology, legal to be able to provide expert advice when needed by the spinoffs.

- Scan and store information regarding new technologies that can be used to create value in the market.

- Encourage the idea of entrepreneurship.

- Assist spinoff firms in creation and use of knowledge products so as to contribute to economic growth and development.

\section{CONCLUSION}

There is little doubt that universities play an important role in regional and national economic development through education and research. Scholars have also promoted the idea that universities should go beyond education and research and undertake the third mission of direct interaction and contribution to the industry through university spinoffs.

Just like management of any other enterprise, University Spinoffs also experience many challenges in effective management. Literature offered evidence and authors found that it starts right after research results are patented by the Technology Licensing/Transfer Office of Universities and are ready to be commercialized. Beginning with Product Development, many entrepreneur face the Technology Push
Problem as it is easy to create a technology but to market it requires consumer consciousness of the technology as well. Finance is said to be the backbone of any company and the same is also true in the case of university spinoffs. They face a lot of financial problems because investors might not be sure of the success of these endeavors. Market Uncertainty is a challenge for any kind of enterprise and the same applies for university spinoffs as well. Just as financial capital is a challenge for university spinoffs, the same also applies for the unique Human Capital that can make or break the company. Finally, the most common challenge of formulating a strong yet workable Business Strategy stands true in case of university spinoffs too.

It was also found that technology is central to business strategy, although strategic management encompasses much more than just technology. Paper also explored the difficulties that these spinoffs face to capture profits from technology without a strategy for exploiting the competitive openings that new technologies provide. It can be understood that research and development create valuable opportunities, but these are converted to survival, growth and profits only through a linkage between technology and business strategy. Thus, there exists a dynamic relationship between technology and strategy. Paper offers a deeper insight into the understanding that university spinoffs face the challenges thrown on to them by the business environment without being really prepared for them. To mitigate the risk of failure and to provide them with a cushion of assistance, many universities today have incubators where the start - up companies can have a foundation from where they can leap high to success. Business incubators play a key role in providing assistance to nascent entrepreneurs, particularly in the initial stages of their firm's life-cycle. Such support gives the start-up companies a relatively secure environment and a head start over others.

\section{REFERENCES}

Aldrich, H. (1999). Organizations evolving. Sage.

Ali, A. (1994). Pioneering versus incremental innovation: review and research propositions. Journal of product innovation management, 11(1), 46-61. https://doi.org/10.1111/1540-5885.1110046

Allen, D. N., \& McCluskey, R. (1990). Structure, policy, services, and performance in the business incubator industry. Entrepreneurship Theory and Practice, 15(2), 61-77. https://doi.org/10.1177/104225879101500207

Allen, D. N., \& Rahman, S. (1985). Small business incubators: a positive environment for entrepreneurship. Journal of Small Business Management, 23(3), 12-22.

Applegate, L. M., \& Gogan, J. L. (1995). Electronic Commerce: Trends and Oppportunities. Harvard Business School Pub.

Atlan, T. (1987). Bring together industry and university engineering schools. In Getting More Out of R\&D and Technology, The Conference Board, Research Report (Vol. 904).

Bee, E. (2004). Small business vitality \& economic development. Economic Development Journal, 3(3), 7-15.

Bergek, A., \& Norrman, C. (2008). Incubator best practice: A framework. Technovation, 28(1), 20-28. https://doi.org/10.1016/ j.technovation.2007.07.008 
Bigliardi, B., Galati, F., \& Verbano, C. (2013). Evaluating Performance of University Spin-Off Companies: Lessons from Italy. Journal of Technology Management \& Innovation, 8(2), 178-188. https://doi.org/10.4067/S0718-27242013000200015

Carayannis, E. G., Rogers, E. M., Kurihara, K., \& Allbritton, M. M. (1998). High-technology spin-offs from government $R \& D$ laboratories and research universities. Technovation, 18(1), 1-11. https://doi.org/10.1016/S0166-4972(97)00101-6

Casson, M. (1982). The entrepreneur: An economic theory. Rowman \& Littlefield.

Chrisman, J. J., Hynes, T., \& Fraser, S. (1995). Faculty entrepreneurship and economic development: The case of the University of Calgary. Journal of business venturing, 10(4), 267-281. https://doi.org/10.1016/0883-9026(95)00015-Z

Cohen, W. M., Nelson, R. R., \& Walsh, J. P. (2002). Links and impacts: the influence of public research on industrial R\&D. Management science, 48(1), 1-23. https://doi.org/10.1287/mnsc.48.1.1.14273

D'Este, P., \& Patel, P. (2007). University-industry linkages in the UK: What are the factors underlying the variety of interactions with industry?. Research Policy, 36(9), 1295-1313. https://doi.org/10.1016/j.respol.2007.05.002

Dollinger, M. J. (2003). Entrepreneurship. Prentice Hall.

Doutriaux, J., \& Barker, M. (1995). The university-industry relationship in science and technology (No. 11). Gouvernement du Canada-Industry Canada.

Etzkowitz, H., \& Leydesdorff, L. (2000). The dynamics of innovation: from National Systems and "Mode 2" to a Triple Helix of university-industry-government relations. Research policy, 29(2), 109-123. https://doi.org/10.1016/S0048-7333(99)00055-4

Feeser, H. R., \& Willard, G. E. (1990). Founding strategy and performance: A comparison of high and low growth high tech firms. Strategic Management Journal, 11(2), 87-98. https://doi.org/10.1002/smj.4250110202

Görling, S. (2006). Methods for assessing technology transfer-an overview (No. 31). Royal Institute of Technology, Department of Industrial Economics and Management. https://doi.org/10.2139/ ssrn. 945134

Grimaldi, R., \& Grandi, A. (2005). Business incubators and new venture creation: an assessment of incubating models. Technovation, 25(2), 111-121. https://doi.org/10.1016/S0166-4972(03)00076-2

Hackett, S. M., \& Dilts, D. M. (2004). A systematic review of business incubation research. The Journal of Technology Transfer, 29(1), 55-82. https://doi.org/10.1023/B:JOTT.0000011181.11952.0f

Heirman, A., \&Clarysse, B. (2007). Which Tangible and Intangible Assets Matter for Innovation Speed in Start-Ups?*. Journal of Product Innovation Management, 24(4), 303-315. https://doi.org/10.1111/j.1540-5885.2007.00253.x

Huffman, D., \& Quigley, J. M. (2002). The role of the university in attracting high tech entrepreneurship: A Silicon Valley tale. The Annals of Regional Science, 36(3), 403-419. https://doi.org/10.1007/s001680200104

Jaffe, A. B. (1989). Real effects of academic research. The American Economic Review, 957-970.
Kerin, R. A., Varadarajan, P. R., \& Peterson, R. A. (1992). First-mover advantage: A synthesis, conceptual framework, and research propositions. The Journal of Marketing, 33-52. https://doi.org/10.2307/1251985

Leydesdorff, L., \& Etzkowitz, H. (1998). The triple helix as a model for innovation studies. Science and public policy, 25(3), 195-203.

Lockett, A., \& Wright, M. (2005). Resources, capabilities, risk capital and the creation of university spin-out companies. Research Policy, 34(7), 1043-1057. https://doi.org/10.1016/j.respol.2005.05.006

Lundvall, B. Ä., \& Johnson, B. (1994). The learning economy. Journal of industry studies, 1(2), 23-42. https://doi.org/10.1080/ 13662719400000002

Martin, M. J. (1994). Managing innovation and entrepreneurship in technology-based firms. New York: Wiley.

Merton, R. K. (1973). The sociology of science: Theoretical and empirical investigations. University of Chicago press.

Mian, S. A. (1994). US university-sponsored technology incubators: an overview of management, policies and performance. Technovation, 14(8), 515-528. https://doi.org/10.1016/0166-4972(94)90151-1

Mintzberg, H. (1979). The structuring of organizations: A synthesis of the research. University of Illinois at Urbana-Champaign's Academy for Entrepreneurial Leadership Historical Research Reference in Entrepreneurship.

Mowery, D. C., \& Sampat, B. N. (2005). Universities in national innovation systems. The Oxford handbook of innovation, 209-39. https://doi.org/10.1093/oxfordhb/9780199286805.003.0008

Nelson, R. R. (1991). Why do firms differ, and how does it matter?. Strategic management journal, 12(S2), 61-74. https://doi.org/10.1002/smj.4250121006

Nicolaou, N., \& Birley, S. (2003). Academic networks in a trichotomouscategorisation of university spinouts. Journal of Business Venturing, 18(3), 333-359. https://doi.org/10.1016/S08839026(02)00118-0

Peters, L., Rice, M., \& Sundararajan, M. (2004). The role of incubators in the entrepreneurial process. The Journal of Technology Transfer, 29(1), 83-91. https://doi.org/10.1023/B:JOTT.0000011182.82350.df

Roberts, E. B. (1991). Entrepreneurs in high technology. New York: Oxford University Press. https://doi.org/10.1093/acprof:oso/ 9780195067040.001.0001

Roberts, E. B., \& Malonet, D. E. (1996). Policies and structures for spinning off new companies from research and development organizations. $R \& D \quad$ Management, 26(1), 17-48. https://doi.org/10.1111/j.1467-9310.1996.tb00927.x

Rothaermel, F. T., \& Thursby, M. (2005). Incubator firm failure or graduation?: The role of university linkages. Research policy, 34(7), 1076-1090. https://doi.org/10.1016/j.respol.2005.05.012

Rothberg, R. R. (2005). Managing Strategic Innovation and Change: A Collection of Readings. Journal of Product Innovation Management, 22(5), 458-458. https://doi.org/10.1111/j.1540-5885.2005.00141 -5.x

Shane, S. (2004). Academic entrepreneurship. Edward Elgar Publishing. https://doi.org/10.4337/9781843769828 
Shane, S. A. (2003). A general theory of entrepreneurship: The individualopportunity nexus. Edward Elgar Publishing.

Shane, S., \& Stuart, T. (2002). Organizational endowments and the performance of university start-ups. Management science, 48(1), 154170. https://doi.org/10.1287/mnsc.48.1.154.14280

Slaughter, S., \& Leslie, L. L. (1997). Academic capitalism: Politics, policies, and the entrepreneurial university. The Johns Hopkins University Press, 2715 North Charles Street, Baltimore, MD 21218-4319.

Smilor, R. W., Gibson, D. V., \& Dietrich, G. B. (1990). University spinout companies: technology start-ups from UT-Austin. Journal of business venturing, 5(1), 63-76. https://doi.org/10.1016/08839026(90)90027-Q

Stalk, G., \& Hout, T. M. (1990). Competing against time: How time-based competition is reshaping global markets. New York: Free Press.

Stankiewicz, R. (1994). Spin-off companies from universities. Science and Public Policy, 21(2), 99-107.

Stinchcombe, A. L. (2000). Social structure and organizations. Advances in Strategic Management, 17, 229-259. https://doi.org/10.1016/ S0742-3322(00)17019-6
Tornatzky, L. G., Waugaman, P. G., \& Casson, L. (1995). Benchmarking best practices for university-industry technology transfer.

Tushman, M. L., \& Anderson, P. (1986). Technological discontinuities and organizational environments. Administrative science quarterly, 439-465. https://doi.org/10.2307/2392832

vanGorp, D., \& Jagersma, P. K. (2004). Spin-Out Business Model: A Strategic Tool for Innovative Growth, Entrepreneurship and Flexibility in the Service Sector. Technology, 20(27), 51.

Vohora, A., Wright, M., \& Lockett, A. (2004). Critical junctures in the development of university high-tech spinout companies. Research Policy, 33(1), 147-175. https://doi.org/10.1016/S0048-7333(03) 00107-0

Wu, S. Y. (1989). Production, entrepreneurship, and profits. Oxford: Basil Blackwell.

Zahra, S. A. (1996). Technology strategy and financial performance: examining the moderating role of the firm's competitive environment. Journal of Business Venturing, 11(3), 189-219. https://doi.org/10.1016/0883-9026(96)00001-8 